Creative Commons User License: CC BY-NC-ND

Abstracted by: EBSCOhost, Electronic Journals Service (EJS), Google Scholar, Journal Seek, Scientific Commons,

Food and Agricultural Organization (FAO), CABI and Scopus
Journal of Agricultural Extension

Vol. 23 (4) October, 2019

ISSN(e): 24086851; ISSN(Print); 1119944X

http://journal.aesonnigeria.org

http://www.ajol.info/index.php/jae

Email: editorinchief@aesonnigeria.org

\title{
Perception of Organic Farming among Urban Vegetable Farmers in Delta Central Agricultural Zone
}

https://dx.doi.org/10.4314/jae.v23i4.9

\section{Ighoro, Alexander}

Department of Produce Inspection,

Delta State Ministry of Agriculture and Natural Resources

Asaba, Nigeria.

Email: ighoroalexander@gmail.com

Phone: 08033486720

\section{Alakpa, Samson Onoriobaefe E.}

Department of Agricultural Economic and Extension

Benson Idahosa University

Benin City, Edo State, Nigeria.

Email: salakpa@biu.edu.ng

Phone: 08032283864

\section{Koyenikan, Margaret}

Department of Agricultural Economics \& Extension

University of Benin, Benin City, Edo State, Nigeria.

Email: margaret.koyenikan@uniben.edu

Phone: 08142108098

\section{Awhareno, Uyoyou Sidney}

Department of Produce Inspection,

Delta State Ministry of Agriculture and Natural Resources

Asaba, Nigeria.

Email: uyoyousidney@gmail.com

Phone: 08023883377

\section{Abstract}

This study examined the perception of urban vegetable farmers on organic farming. Data were collected from 102 respondents using a multi stage sampling technique and a structured interview schedule. Results indicate that the majority of the farmers were females (89.2\%) with (87.25\%) married and mean age 40.8. Only 10.8\% had no education. Most respondents (70.59\%) went into vegetable farming as a means of secondary income and for home consumption (82.35\%). Major constraints faced by respondents include bulkiness of organic materials $(\bar{x}=3.34)$, inability to handle/preserve/process organic material $(\bar{x}=2.99)$ and no access to training on organic vegetable farming $((\bar{x}=3.79)$. Perception of farmers on organic farming was generally unfavourable (58.8\%) however, it was significantly correlated to age $(r=$ $0.171)$, marital status $\left(\chi^{2}=17.96, p=0.05\right)$ and educational attainment ( $\chi^{2}=$ 6.397, $p=0.05$ ). It concluded that farmers used organic farming to improve on their income and soil nutrient status and as such recommended appropriate institutional support to encourage organic farming. 
Creative Commons User License: CC BY-NC-ND

Abstracted by: EBSCOhost, Electronic Journals Service (EJS), Google Scholar, Journal Seek, Scientific Commons,

Food and Agricultural Organization (FAO), CABI and Scopus
Journal of Agricultural Extension

Vol. 23 (4) October, 2019

ISSN(e): 24086851; ISSN(Print); 1119944X

http://journal.aesonnigeria.org

http://www.ajol.info/index.php/iae

Email: editorinchief@aesonnigeria.org

Keywords: Organic farming, urban and vegetable farmers.

\section{Introduction}

There is increasing population density across urban centres around the world and this has necessitated various economic activities among urban dwellers of which vegetable gardening is one. The importance of vegetable gardening in improving farm income through the diversification of the agricultural production system cannot be overemphasized. Regmi (2014) opined that urban population in sub Saharan Africa will triple in the next 40 years and this will have implication for agricultural and economic activities such as vegetable gardening. Urban vegetable gardening as a common practice among urban dwellers is either practiced using conventional chemical fertilisers or manure depending on availability, technical know-how and cost elements (Global Agricultural Information Network (GAIN), 2014). Urban farming is recognised as a growing phenomenon in Nigeria and it involves the growing of plants, raising of animals for food and others uses, as well as other related activities such as production and delivery of inputs within urban settlements (Nnadi, Aja, Nnadi, Ani, Anaeto, Akwiwu, Agomuo and Elei, 2014). Vegetable gardening has become an essential part of the economic activities of urban dwellers and as opined by Ibeanuchi (2015), the production and economic value of vegetable production ranges from ease of production, less land requirement, quick source of income and livelihood for all class of people and the relatively high returns to producers.

Vegetable are very essential parts of people's diet in most African cities and have succulent parts that are eaten cooked or in raw forms. Beyond generating income for producers, they are very good sources of essential nutrients and vitamins needed for effective functioning of the human system. Organic vegetable farming which involves use of natural materials for fertilization is gaining wide acceptance in urban areas and provides tremendous economic benefits to small scale farmers in addition to reducing pollution, improvement of soil quality, conservation and improvement of top soil compaction and on the overall ensures long term sustainability of agriculture (GAIN, 2014). In another vein, Yusuf and Abbas (2012) posited that organic vegetable farming is a growing agricultural activity in most urban centre in Nigeria and this is a result of the need to survive and earn extra income by low income urban peasants. According to Mgbenka, Onwubuya and Ezeano (2015), the philosophy of organic food production is to maintain ecological balance and soil integrity and a reduction in the use of synthetic herbicides, pesticides, chemical fertilisers and growth hormones with the goal of protecting and preserving the world's natural resources, production of safe and healthy food. They stressed that organic farming is a better option for productivity, better management of soil and sustainability. In spite of this, pest and diseases and other associated challenges have been linked with organic vegetable farming and this in turn reduces availability, market and nutritional value of vegetables. It is evident that continuous use of fertiliser and pesticides will lead to biodegradation of the environment with serious health implications for man and animal. Thus, making urban vegetable farming a veritable means of sustainability in agriculture. Urban organic vegetable gardening according to Atoma, (2015), has been an age-long practice among rural and urban dwellers in Delta State and have contributed to their livelihood. 
Creative Commons User License: CC BY-NC-ND

Abstracted by: EBSCOhost, Electronic Journals Service (EJS), Google Scholar, Journal Seek, Scientific Commons,

Food and Agricultural Organization (FAO), CABI and Scopus
Journal of Agricultural Extension

Vol. 23 (4) October, 2019

ISSN(e): 24086851; ISSN(Print); 1119944X

http://journal.aesonnigeria.org

http://www.ajol.info/index.php/iae

Email: editorinchief@aesonnigeria.org

Considering the critical nature of organic vegetable farming, it becomes imperative to access farmer's perception of organic vegetable farming among urban dwellers in Delta State. Farmer's perception or disposition to organic farming, innovation or practices will affect their levels of use or application in their overall farming activities with attendant implication for productivity. The study therefore examined respondent's reasons for engaging in vegetable farming, their perception and the perceived constraints to organic vegetable farming

\section{Methodology}

The study was carried out in Delta State, Nigeria. It lies between longitude $5^{\circ} 00^{\prime \prime}$ and 6 ${ }^{\circ} 45^{\prime \prime}$ East and latitude $5^{\circ} 00^{\prime \prime}$ and 6 ${ }^{\circ} 30^{\prime \prime}$ North and flanked by Edo State to the North, Ondo to the South West, Anambra to the East and Bayelsa to the South East. It has an average rainfall of $2000 \mathrm{~mm}$ per annum, temperature of $30.4-36.4^{\circ} \mathrm{C}$ and relative humidity of $56 \%-86 \%$ per annum. Administratively, the State is divided into three (3) senatorial districts made up of twenty-five (25) local government areas (LGAs) with two agro ecological zones - riverine and upland. The climatic condition of the State is favourable for all year round farming. Major crops grown include cassava, yam, vegetables, maize, rubber and oil Palm. A multistage sampling procedure was used to select respondents for the study. The first stage involves the purposive selection of Delta Central Agricultural Zone because of its urban nature and prominence in vegetable farming. This was followed by the purposive selection of 3 local government areas (LGAs) of Uvwie, Okpe and Ughelli North because of their urban nature and high density of vegetable farmers.

From the LGAs, 6 urban communities were selected and from the communities using a simple random sampling technique 102 respondents were selected for the study. Primary data were collected using a structured interview schedule. Frequencies, percentages and mean were used to describe respondents' reasons for engaging in vegetable farming and the constraint faced in organic vegetable farming, while correlation coefficient and chi square measured at $5 \%$ significance were used to access the relationship between perception of respondents and their socioeconomic characteristics

Respondents reason for engaging in vegetable gardening was measured by asking them to respond to a set of benefits with a "Yes' or "No". Thereafter percentages were used to present results. Constraints to organic farming was measured using a 4-point scale of strongly agree (4), agree (3), disagree (2) and strongly disagree (1) and a cut-off point of 2.5 was used to determine the significant constraints. Similarly, the perception of respondent to vegetable farming was assessed using 14 statements on a 4-point scale of strongly agree (4), agree (3), disagree (2) and strongly disagree (1) and a cut-off point of 2.5 was used to ascertain respondent's perception. With a calculated grand mean of 2.68 , respondent's perception was classified as favourable and unfavourable. 
Creative Commons User License: CC BY-NC-ND

Abstracted by: EBSCOhost, Electronic Journals Service (EJS), Google Scholar, Journal Seek, Scientific Commons,

Food and Agricultural Organization (FAO), CABI and Scopus
Journal of Agricultural Extension

Vol. 23 (4) October, 2019

ISSN(e): 24086851; ISSN(Print); $1119944 X$

http://journal.aesonnigeria.org

http://www.ajol.info/index.php/iae

Email: editorinchief@aesonnigeria.org

\section{Results and Discussion}

\section{Reasons for Engaging in Vegetable Farming}

Table 1 shows that the ease of cultivation (97.06\%) and home consumption $(87.25 \%)$ were the primary reasons for engaging in vegetable gardening. The need to earn extra income $(70.59 \%)$ was another reason for their involvement. Thus the need to meet up family nutritional requirement and the economic gains involve is a driving force among respondents

Table 1: Reasons for engaging in vegetable farming

\begin{tabular}{ll}
\hline Reason & $\%^{*}(\mathbf{n}=\mathbf{1 0 2})$ \\
\hline Minimal investment in inputs & $64.71^{*}$ \\
Passive/extra income & $70.59^{*}$ \\
Past time/pleasure & $18.63^{*}$ \\
For Home consumption & $82.35^{\star}$ \\
Easy to produce & $97.06^{*}$ \\
To reduce boredom & $4.90^{*}$ \\
\hline
\end{tabular}

${ }^{*}$ Multiple responses. Source: Field Survey, 2018.

\section{Perceived Constraints Faced by Respondents}

Table 2 indicates that respondents are confronted with many multidimensional challenges which include inability to secure enough organic fertiliser $\quad(\bar{x}=2.88)$, bulkiness and difficulty in transportation $(\bar{x}=3.34)$ and Insufficient knowledge on use and application of organic manure in vegetable farming $(\bar{x}=3.10)$. Lack of technical know-how was identified by Mgbenka (2015) as a major constraint to organic farming in Nigeria. Other perceived constraint identified as significant were Lack of sufficient land space $(\bar{x}=3.66)$, Inadequate capital for farm expansion $(\bar{x}=3.41)$ and Lack of adequate water supply for irrigation during the dry season $(\bar{x}=3.32)$. 
Creative Commons User License: CC BY-NC-ND

Abstracted by: EBSCOhost, Electronic Journals Service (EJS), Google Scholar, Journal Seek, Scientific Commons,

Food and Agricultural Organization (FAO), CABI and Scopus
Journal of Agricultural Extension

Vol. 23 (4) October, 2019

ISSN(e): 24086851; ISSN(Print); $1119944 X$

http://journal.aesonnigeria.org

http://www.ajol.info/index.php/jae

Email: editorinchief@aesonnigeria.org

Table 2: Perceived constraints to organic vegetable farming

\begin{tabular}{llc}
\hline Constraints & Mean & SD \\
\hline Inability to secure adequate organic manure & 2.88 & 0.51 \\
Bulkiness and difficulty in transportation of organic manures & 3.34 & 0.53 \\
Difficulty in preservation and handling of organic manure & 2.99 & 0.48 \\
Health hazard & 1.98 & 0.58 \\
Organic manure are expensive & 2.00 & 0.55 \\
Insufficient knowledge on use and application of organic & 3.10 & 0.52 \\
manure in vegetable farming & 3.79 & 0.47 \\
No access to training on organic vegetable farming & 1.80 & 0.53 \\
Low price of organic vegetables & 3.21 & 0.55 \\
Poor knowledge of the nutritional value of organic vegetables & 2.76 & 0.54 \\
Competition with weed & 3.66 & 0.49 \\
Lack of sufficient land space & 3.41 & 0.52 \\
Inadequate capital for farm expansion & 3.32 & 0.52 \\
Lack of adequate water supply for irrigation during the dry \\
season
\end{tabular}

>2.5 Significant. Source: Field Survey, 2018.

\section{Perception of Organic Vegetable Farming}

Respondents agreed that organic vegetable farming produces safe and healthy vegetables $(\bar{x}=3.04)$ but that organic vegetables are expensive $(\bar{x}=1.90)$ with organic vegetable farming requiring more efforts and time $(\bar{x}=3.07)$. Even though they expressed confidence that organic farming leads to increased productivity $(\bar{x}=$ 3.20) they however indicated that there is insufficient training and awareness on organic vegetable farming $(\bar{x}=3.02)$.

Respondents levels of perception of organic vegetable farming was categorized using the overall perception mean indicates that $58.8 \%$ of respondents had unfavourable perception and $41.2 \%$ had favourable perception. The implication is that the majority of the organic vegetable farmers prefer to use other means of fertilization in spite of the perceived benefits of organic farming. This results corroborates the findings of Oladeji et al (2015) that most vegetables farmers have unfavourable perception of organic farming practices 
Creative Commons User License: CC BY-NC-ND

Abstracted by: EBSCOhost, Electronic Journals Service (EJS), Google Scholar, Journal Seek, Scientific Commons,

Food and Agricultural Organization (FAO), CABI and Scopus
Journal of Agricultural Extension

Vol. 23 (4) October, 2019

ISSN(e): 24086851; ISSN(Print); $1119944 X$

http://journal.aesonnigeria.org

http://www.ajol.info/index.php/iae

Email: editorinchief@aesonnigeria.org

Table 3: Perception of respondents to organic vegetable farming

\begin{tabular}{|c|c|c|}
\hline Perception Variable & Mean & SD \\
\hline $\begin{array}{l}\text { Organic vegetable farming produces safe and healthy } \\
\text { vegetables }\end{array}$ & 3.04 & 0. \\
\hline Organic vegetables are expensive & 1.90 & 1.20 \\
\hline arming require & 3.07 & 0.82 \\
\hline does not impact on the & 2.13 & 0 \\
\hline ible farming can only be practiced effectively by & 2.33 & 0.87 \\
\hline ased productivity & 3.20 & 0.89 \\
\hline manures could be a source of pathogens and & 2.99 & 0. \\
\hline a fertilisers are cheaper compare to organic manure & 1.67 & 0.94 \\
\hline le farming can only be practiced on small & $2 .($ & 1.34 \\
\hline ter and quicker & 3.03 & $0 . \varepsilon_{2}$ \\
\hline production because & 2. & 1.20 \\
\hline getable & 2.88 & 1.89 \\
\hline $\begin{array}{l}\text { There is insufficient training and awareness of organic } \\
\text { vegetable farming }\end{array}$ & 3. & 0 \\
\hline Government support to organic vegetable farmers is low & 3.28 & 0.64 \\
\hline
\end{tabular}

${ }^{*}$ Multiple responses

Source: Field Survey, 2018.

\section{Relationship between Selected Socioeconomic Characteristics and Perception of Organic Vegetable Farming}

Table 4 shows that there is a significant relationship between marital status $\left(\chi^{2}=\right.$ 17.96, $p=0.001)$ and educational status $\left(\chi^{2}=6.397, p=0.041\right)$ and their perception of organic farming. Thus married people and the more educated ones will be more predispose to organic vegetable farming. This may be due to the fact that as the family grows there will be need to augment family income and use home grown strategies like vegetable farming in providing the nutritional and dietary need. 
Creative Commons User License: CC BY-NC-ND

Abstracted by: EBSCOhost, Electronic Journals Service (EJS), Google Scholar, Journal Seek, Scientific Commons,

Food and Agricultural Organization (FAO), CABI and Scopus
Journal of Agricultural Extension

Vol. 23 (4) October, 2019

ISSN(e): 24086851; ISSN(Print); 1119944X

http://journal.aesonnigeria.org

http://www.ajol.info/index.php/iae

Email: editorinchief@aesonnigeria.org

Table 4: Farmers perception and socioeconomic characteristics

\begin{tabular}{lcc}
\hline \multicolumn{1}{c}{$\begin{array}{c}\text { Socioeconomic } \\
\text { Characteristics }\end{array}$} & $\chi^{2}$ Value & Degree of Freedom \\
\hline Sex & 0.12 & 1 \\
Marital Status & $17.96^{\star}$ & 3 \\
Religion & 3.184 & 2 \\
Education & $6.397^{\star}$ & 3 \\
\hline
\end{tabular}

Source: Field Survey, 2018.

The results in Table 5 show that age $(r=0.171, p \leq 0.05)$, farming experience $(r=$ $0.189, p \leq 0.05)$ and household size $(r=0.125, p \leq 0.05)$ had significant relationship with respondents' perception of organic vegetable farming. Thus, as respondents gets older, they become more positively disposed to organic vegetable farming. This however contradicts the report of Edeoghon (2015) that as age increases, participation of people in vegetable farming decreases. In the same vein, the more the household size, the more the likelihood of engaging in organic vegetable farming. It could also be inferred that as the family grows bigger, there is the need to meet the nutritional requirement through economic activities like vegetable gardening.

Table 5: Relationship between respondent's socioeconomic characteristics and perception of organic farming

\begin{tabular}{lc}
\hline Socioeconomic Characteristics & $\begin{array}{c}\text { Correlation } \\
(\mathbf{r})\end{array}$ \\
\hline Age & $0.171^{*}$ \\
Farm experience & $0.189^{\star}$ \\
Farm size & -0.033 \\
Household size & $0.125^{\star}$ \\
\hline
\end{tabular}

Source: Field Survey, 2018.

\section{Conclusion and Recommendation}

The majority of organic vegetable farmers in the area were producing at subsistence. Lack of technical know- how and poor institutional supports among others were major constraints to the vegetable gardening activities and this perhaps accounted for the unfavourable perception of respondents to organic vegetable gardening. Intensive awareness and enlightenment on the benefits and potentials of organic farming be carried out. 
Creative Commons User License: CC BY-NC-ND

Abstracted by: EBSCOhost, Electronic Journals Service (EJS), Google Scholar, Journal Seek, Scientific Commons,

Food and Agricultural Organization (FAO), CABI and Scopus
Journal of Agricultural Extension

Vol. 23 (4) October, 2019

ISSN(e): 24086851; ISSN(Print); 1119944X

http://journal.aesonnigeria.org

http://www.ajol.info/index.php/iae

Email: editorinchief@aesonnigeria.org

\section{References}

Atoma, C. N. (2015). Analysis of rural households' use of organic farming practices in South South, Nigeria. PhD thesis submitted to the department of Agricultural Economics and Extension, Federal University of Technology, Owerri, Nigeria.

Edeoghon, C.O. and Anozie, O. (2015). Urban women participation in urban gardening in Ondo Senatorial of Ondo State, Nigeria. Nigerian Journal of Rural Sociology, 16 (2), 55-72.

Global Agricultural Information Network (GAIN) (2014). Organic agriculture in Nigeria: USDA Foreign Agricultural Services.

Ibeawuchi, I. I., Okoli, N. A., Alagba, R.A., Ofor, M.O., Emma- Okafor, I.C., Peter - Onoh, C.A., and Obiefuna, J. C. (2015). Fruit and vegetable crop production in Nigeria: The gains, challenges and the way forward. Journal of Biology, Agriculture and Healthcare. 5 (2).

Iheke, O.R. and Ihuoma, U. (2015). Effect of urbanisation on agricultural production in Abia State. International Journal of Agricultural Science, Research and Technology in Extension and Education Systems, 5(2), 83-89.

Mgbenka, R.N., Onwubuya, E.A., and Ezeano C.I. (2015). Organic farming in Nigeria: Need for popularization and policy. World Journal of Agricultural Sciences, 11(6).

Nnadi, F. N., Aja, O.O., Nnadi, C.D., Ani, A.O.,Anaeto, F.C., Akwiwu, U. N., Agomuo, C. I., and Elei, C. P. (2014). Urban farmers' adoption of improved dry season vegetable production techniques in Owerri Municipal Council of Imo State, Nigeria. Journal of Agricultural Extension, 18 (2).

Oladeji, J.O., Ajadi, S.O., Oyesola, O.B., and Sangotegbe, N.S. (2015). Vegetables farmers perception of adoption of organic farming in Oyo State, Nigeria. Nigerian Journal of Rural Extension and Development, 9: 53 - 59

Regmi, A. (2014). The Push-Pull effect of urbanisation in agriculture. CGIAR Consortium, African Studies Centre, Netherland. June 17, 2014.

Yusuf, O.R. and Abbass I.I. (2012). Variation in productivity of urban vegetable cultivators in Ilorin, Nigeria. International Journal of Development and Sustainability, 1(3), 11581169. 